Contributor: Jasmine Shadrack.

Institution: The University of Northampton, United Kingdom.

Job Title: Senior Lecturer in Popular Music.

Email Address: jasmine.shadrack@northampton.ac.uk

Postal Address: MR62, Avenue Campus, the University of Northampton, St George's Avenue, Northampton. NN2 6JD.

Title: Mater Omnium and the Cosmic Womb of the Abyss: nomadic interiorities and matrifocal black metal performance.

Key Words: Feminism, Black Metal, Subjectivity, Kristeva, Jouissance, Abjection, Sublime Alienation, Deject, The Corpse, Matrifocal Performance

\title{
Abstract:
}

If a woman cannot feel comfortable in her own body, she has no home. (Winterson, J, The Guardian, 29.03.2013).

Black metal is beyond music. It exceeds its function of musical genre. It radiates with its sepulchral fire on every side of culture [...] Black metal is the suffering body that illustrates, in the same spring, all the human darkness as much as its vital impetus. (Lesourd 2013).

Masciandaro's notion of 'the cosmic womb of the abyss' (2010) in black metal theory, suggests a foregrounding of a matrifocal position cosseted and restrained within the patriarchal frame of black metal that at once, performs against it and from within it. The overt masculinity of this subgenre, of metal and popular music structures and the wider socio-cultural metanarrative, means that for a woman to occupy space within black metal, she has to identify the cosmic womb as her own. The process that subsequently unfolds is a subjective self-embodied analysis that, through interpretive performance autoethnography, develops a critical understanding of women and their relationship to black metal. This produces the notion of woman as the female nomad, as Winterson notes, whose inability to feel comfortable in her own body means that she is mediated through patriarchal structures and her home is denied her. Through interpretive performance autoethnography, that sense of home, of the occupation of her interiorities, becomes a tangible active performance; the abyssic void becomes arrested by female black metal performance and the mater omnium ceases her nomadic journey, and finds release.

This paper seeks to analyse female black metal performance through interpretive performance autoethnography. As the guitarist and front woman with the avant-garde black metal band Denigrata, my involvement has meant that the journey to find my home rests within the blackened heart of musical performance. Interpretive performance autoethnography provides the analytical frame through which the cosmic womb of the abyss becomes manifest in Denigrata's music and artobjects. This process identifies and actualises Creed's 'generative archaic mother, constructed within patriarchal ideology, as the primeval 'black hole', the originating womb which gives birth to all life' (1997), exceeding the mystical, all-powerful feminine divine and making her, through black metal performance, wholly human. 


\section{Mater Omnium and the Cosmic Womb of the Abyss: nomadic interiorities and matrifocal black metal performance.}

I identify woman as nomad. Jeanette Winterson suggests that 'if a woman cannot feel comfortable in her own body, she has no home' (The Guardian, 29.03.2013), that her interiorities as displacement suggest 'unbelonging' to herself, owned yet unwanted by patriarchy, by culture. Then I argue that black metal as matrifocal performance, a performance that foregrounds women's subjectivities and narrative, is a space that 'is beyond music. It exceeds its function of musical genre. It radiates with its sepulchral fire on every side of culture [...] Black metal is the suffering body that illustrates, in the same spring, all the human darkness as much as its vital impetus. (Lesourd 2013). The coalescence of female subjectivity with black metal offers new ground in performance theory and feminist debate that provides a space for the trauma a woman experiences living within patriarchy to be excised here.

I apply Julia Kristeva's ideas to my performance in Denigrata, an avant-garde black metal band, that examines abjection, notions of the deject, the corpse and finally jouissance.

\section{Denigrata as Abjection: Fear and Loathing in Black Metal}

Between the subject and the object, lies the abject. Not 'the object facing me, which I name or imagine [that] makes me ceaselessly and infinitely homologous to it; what is abject [...] the jettisoned object, is radically excluded and draws me towards the place where meaning collapses' (2). For Kristeva, the abject is fear and disgust as a response to a signifying system of feminised processes, of repugnance of bodily functions that prevent a clean and proper body being maintained. It is patriarchal revulsion at the female body as the point of origin and its ability to 'disturb identity, systems, [and] order' (4). It abjects and causes abjection, that abjection is 'a terror that dissembles, a hatred that smiles, a passion that uses the body for barter instead of inflaming it, a debtor who sells you up, a friend who stabs you...' (4). It is a dark, seething liminality that 'does not respect borders, positions, [or] rules'.

Much of Kristeva's work in The Powers of Horror (1982) re-reads Freudian psychoanalysis in order to ameliorate its masculinist orthodoxy by providing a woman's theoretical position. She states:

To each ego its object, to each superego its abject. It is not the white expanse or slack boredom of repression, not the translations of desire that wrench bodies, nights, and discourse; rather it is a brutish suffering that "I" puts up with, sublime and devastated, for "I" deposits it to the father's account [...]: I endure it, for I imagine that such is the desire of the other. A massive and sudden emergence of uncanniness, which, familiar as it might have been in an opaque and forgotten life, now harries me as radically separate, loathsome. (2)

This statement highlights patriarchy as the dominant structure and discourse which Kristeva's 'I' suffers against; the uncanniness of a woman's body as home and lover and site for devastation. Women embody the same body as our mothers, the site of all human origin that patriarchy has abused, leaving us as nomads. She states that the 'abject and abjection [...] are primers of my culture' (2). They are also mine. 
Kristeva's use of the performative, meaning-bearer ' $I$ ' in her work means that her subjectivity is foregrounded in amongst her theoretical analyses. She uses her subjective writing position to push back against the masculinist frames she examines. She is also angry, disappointed and sidelined; her emotions underpin the precision of her analyses. What I find particularly engaging is how her use of ' $I$ ' merges the theoretical with the autoethnographic, allowing an immediate identification of her 'self' in the text. And it is a furious self that declamatorily states 'not me. Not that. But not nothing either. A "something" that I do not recognise as a thing. A weight of meaninglessness, about which there is nothing significant, and which crushes me' (2). Through my analysis I have had to work hard to move from one place of intimate partner abuse to another, more liberating space and whilst that has offered me musical meaning, that personal meaning or validation I was seeking is not there, and it too crushes me.

\section{The Corpse}

Much like Kristeva's use of the corpse that functions as the epitome of the abject, I feel that my efforts at live shows, is 'the most sickening of wastes, [...] a border that has encroached upon everything. It is no longer I who expel, "I" is expelled" (3-4). The corpse abjects, as my performance as front woman Denigrata Herself also abjects. I have had to ask myself whether I lose more than I gain by performing, and whether or not this is an abjection of the self that means a form of 'abasing herself' (5) that goes too far.

Semantically, Denigrata Herself as a stage name means 'to denigrate herself' and initially I took this title as a means to create a strategy of resistance, to perform back to the masculinity of black metal and wider culture; if I give myself that name, then I remove that ability from others. After two years of this performance however, it is the Kristevan corpse that is forming, through rejection and negativity of that performance. In my desire to be the 'I 'who expels, I have screamed so much that in so doing, I feel that I am trying to grasp hold of what's left. Benveniste states "I" signifies the person who is uttering the present instance of the discourse containing "I"' (qtd in Denzin 2014) but the 'I' has become exhausted by my containing discourse, it now exists as an empty signifier. My referentiality in this statement is constructed through the use of the performative ' $I$ ', and as Elbaz suggests, 'my personhood is not in this line. The pronoun ' $I$ ' is a shifter, and its only reference is in the discourse that surrounds it' (6). My ' $I$ ' has shifted from meaning something to meaning nothing.

Even the corpse paint does not protect me from the negativity of the live event, although as a mask it helps to deflect. As Denigrata Herself, I am 'the corpse, seen without God [...] the utmost of abjection. It is death infecting life' (4). And I suppose that is what black metal is meant to be, death masquerading as life. Masciandaro states:

There are the torments of each, of all who wrestle in collective solitude with its terrifying discontinuous continuities and continuous discontinuities between the reality of what is loved and the image of thought. And this pain points the way (backwards or forwards?) into the superior, more pleasurable suffering wherein the noble lover, the immoderate cogitator [...], the one who loves thinking about the loved one (black metal), who knows that "loving is also necessarily a speculation...an essentially phantasmatic process, involving both imagination and memory in an assiduous, tormented circling around an image painted or reflected in the deepest self." (2010; 86-87) 
My self-as-corpse in corpse paint, represents 'terrifying discontinuous continuities and continuous discontinuities' in my gendered hybridity that forces a rupture of engagement, that invites negative responses forming Masciandaro's tormented circling around the image painted, and that image is me as Denigrata Herself. I acknowledge a doubling of the self, the separation between me and Denigrata Herself, but as my love for the music intensifies and that love is a connection between the two constructs, my metaphysical comfort dissipates. I am angry that sexism blocks the receipt of our live show and I am angry that abjection-as-fear is so identifiable. To begin with, corpse-paint was worn as a black metal aesthetic signifier, now I wear my corpse-paint as armour, something Daniel calls 'melancholy self-preservation' $(2014 ; 44)$ and that is accurate. Kristeva's corpse that infects life with death is born out on stage through my corpse in corpse-paint as a selfpreservatory mode. It is the 'the social production of a legible outward display of an inward relation to death' (44) that exceeds its black metal signification and obliterates its subject, where 'the abject simultaneously beseeches and pulverises the subject' (Kristeva 5). And I do feel pulverised.

I feel that Denigrata Herself has been rejected from the live event, something I have always felt deeply connected to because she represents a threat; 'it is something rejected from which one does not part, from which one does not protect oneself as from an object. Imaginary uncanniness and real threat, it beckons to us and ends up engulfing us' (4). Since Denigrata began, I have felt that I was so intrinsically connected with it, that it has been something from which one does not part, and that I did not need to protect myself from. Now however, on stage, I feel I want to hide at the back, behind the other band members, because I have come to represent the abject, rotting corpse that signifies the 'place where meaning collapses' (2). My intentions and corporeal signifiers meant something, to me at least. To suddenly embody a void where those meanings and signifiers become exhausted indicates that my interiorities (intentions) and my exteriorities (corporeal signifiers) and their distinction become irrelevant; they become fragmented under the scrutiny of black metal elitists and sexist attitudes.

Denigrata Herself crosses multiple borders (see fig. i), she is a borderline subject that 'constitutes propitious ground for a sublimating discourse' (7) and that discourse leaves me in exile. It is Hunt-Hendrix's haptic void in subjective form, the 'total or maximal level of intensity expressed as feeling [...] but [its] promise is a lie. Only its absence is ever present' $(2010 ; 56)$. In my desire to be an active presence I have ended up as its inversion and at our gigs, I am the obliterating corpse whose substance subtracts. And in black metal terms, Denigrata Herself can be understood as the sublimating haptic void in process. 

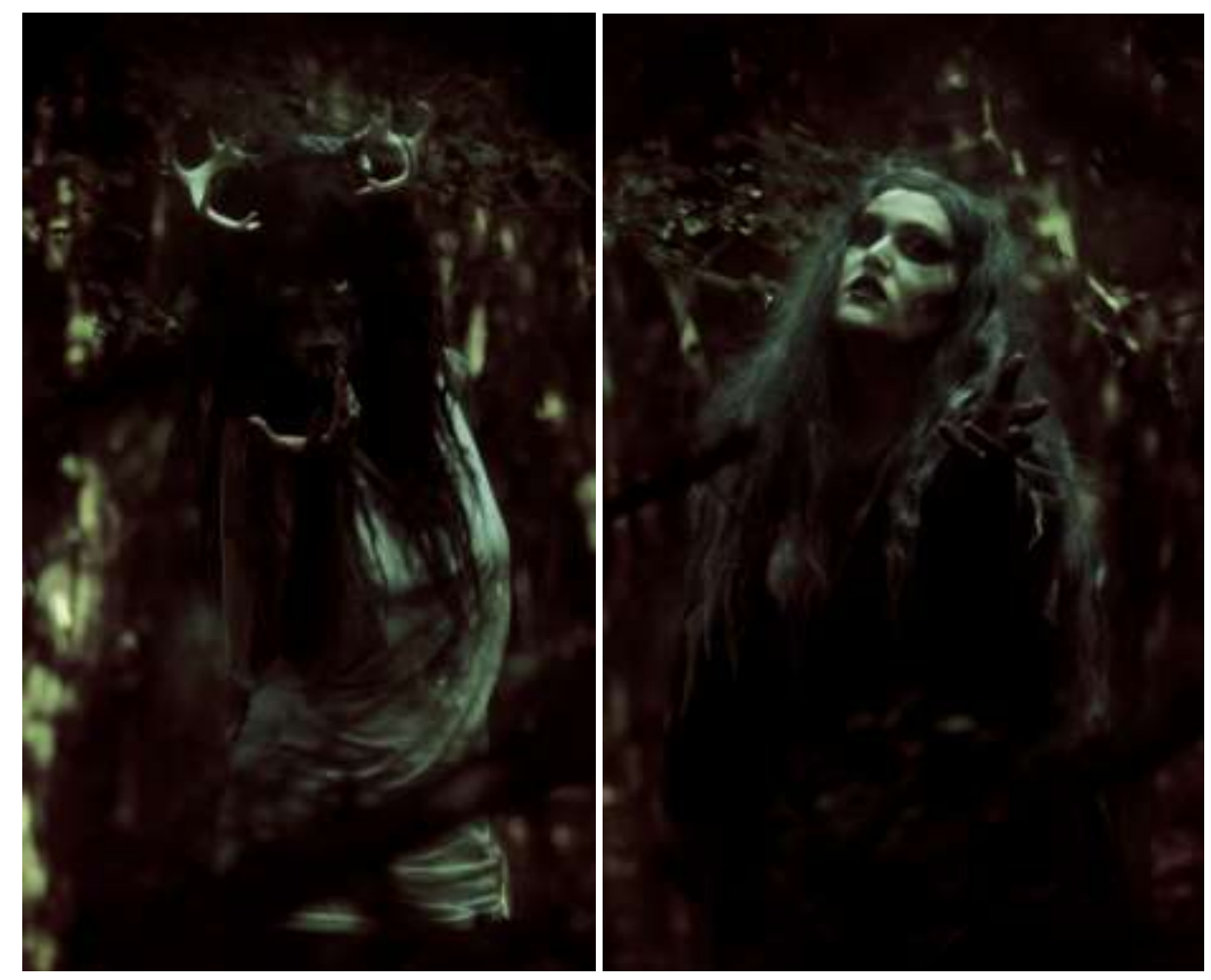

Fig. i. Denigrata Herself.

Fig. ii. Manea.

Photographer: Ester Segarra, 2015.

I feel exiled from the rest of the band because they do not experience the negativity of the live event as I do. I feel exiled from the music I love because I represent a deviant form that is deemed unacceptable and I feel exiled by the totalising affects of this isolation. I am the stray, I am the Kristevan deject. I covet that which is denied me and in so doing, I am a nomad, existing on the margins of 'a land of oblivion' (8) where I constitute a 'non-object, the abject' (8). Kristeva defines the deject as 'one by whom the abject exists [and] is thus a deject who places ([her]self), separates [her]self, situates [her]self, and therefore strays instead of getting [her] bearings, desiring, belongings [...] the deject is in short a stray. [She] is on a journey, during the night, the end of which keeps receding' (8).

Through my performance as Denigrata Herself, something 'other' has been advancing in parallel with my on stage persona. She has made herself known in our perichoresis or total artwork (Hunt-Hendrix 279), through our promotional pictures, artwork, and video. Whilst I had no a priori desire or conceptualisation to create Denigrata Herself in these terms, she has evolved this way nonetheless. Denigrata Herself is a witch, a patriarchally loathed female archetype who embodies freedom of will, sexual desire and power. Witchcraft as a matrifocal, or female-focused, ritual practice (Sonnex 35) has developed, particularly for Denigrata Herself and Manea, into a feminist strategy of resistance that 'evolves [performance] strategies which "consume" their own biases as they expose and erode those of the dominant discourse' (Tiffin 96). Denigrata Herself and Manea's embodiment of the witch archetype on stage and in our perichoresis offers restorative feminism within black metal, subverting its juridical masculinity from inside its dominant discourse. 
Manea and Denigrata Herself certainly evoke this folkloric representation in different ways as can be seen in the above figures. In Peter Grey's Apocalyptic Witchcraft its manifesto states that 'witchcraft is the art of inversion [...] it is revolution and of the power of woman' (16). To say that we felt this in our bones may sound romantic, but it has a real resonance for us. A spiritual path, forged through Denigrata has brought us both to this point. Grey adds 'witchcraft is the recourse of the dispossessed, the powerless, the hungry and the abused. It gives heart and tongue to stones and trees' (14). We have been told at performances that we look like witches, so whatever image these people have in their minds from popular culture is aligning with what they see in us. We did not start out with this in mind however, it has developed as Denigrata has, finding traction and evolution along the way. It is a nomadic deterritorialising of hegemonic femininity, of black metal's masculine frame and has found a home with the most patriarchally hated of folkloric female figures represented by and through us.

\section{She who can Wreck the Infinite: Jouissance and Sublime Alienation}

As sites of abjection, Denigrata Herself and Manea (keys and operatic vocals)co-exist within the same performative space but the abjection functions differently. As Manea performs a more consolidated and outwardly identifiable 'feminine' through the more essentialist gender construction of her instrumentation and vocal delivery, her abjection exists because of her feminine performance within a constructed masculine musical frame. Her musical role informs that reading by enacting a gendered representation through her soprano coloratura and keys. It could be argued then, that her abjection is identifiable by her presence within a normative feminine absence, in a conspicuously masculine artistic form. Denigrata Herself however, forces that abjection further, by presenting an ambiguous gender performance that represents a 'place where meaning collapses' (2). She wears stag horns on stage, representing the antlered high priestess whilst playing guitar and screaming; the role of guitarist and vocalist, two previously designated masculine performances assimilated into one role, represents a gendered musical excess; Denigrata Herself is too much. Perhaps both Manea and Denigrata Herself are two sides of the same coin, both castrated and castrators negotiating the 'precocious narcissistic wound' (158) of female abjection. Both figures can be read as Kristeva's 'two-faced mother [who] is perhaps the representation of the baleful power of women to bestow mortal life' (158). I extend this concept to include the creation of music, instead of life, whose calamitous power shifts from one to the other. Through the performative meaningbearer ' $l$ ', the shifter whose nomadic function 'takes meaning only within the parameters of the discursive event' (Elbaz 6) implies that Denigrata's discursivity creates a deviating and abject performance by splitting the mother in two; two representations of the feminine from one patriarchally constructed singular category of 'women', a category that feminist theory states does not exist (de Beauvoir, 1997 37; Irigaray, 1985 23; Kristeva, 1982 209; Wittig, 1991 4) whilst juridical hegemony continues to construct and perpetuate it. And black metal represents this producing and reproducing systemic gender essentialism. Women are not the phallus and so we must move aside.

Both Manea and Denigrata Herself are without and yet have the phallus, the castrated female body with the power to castrate through our performance on stage. We lack the phallus because we are women and are therefore an abjecting force rather than a stabilising, masculine one. We have the phallus because we assume an encoded masculine space on stage. This emasculating potentiality of both figures causes disruption to black metal's normative practice; women 
performing black metal reinforces our position as dejects; we have strayed somewhere we are not supposed to be. There is a phobic response to this performance that only reveals itself in the minutiae of interactions. The orthodox, juridical nature of black metal enacts a paternal prohibition for women performers that tells us we are only ever tolerated. Subjectively I can feel like a gendered unification all I want but that does not prevent prohibition at live gigs; objectively I am treated as a woman who is in the wrong place, doing a man's job. Kristeva states:

What we designate as "feminine" [...] will be seen as "other" without a name, which subjective experience confronts when it does not stop at the appearance of its identity. Assuming that any Other is appended to the triangulating function of the paternal prohibition, what will be dealt with here, beyond and through the paternal function, is a coming face to face with the unnameable otherness [...] implied by the confrontation with the feminine [...] Abjection, or the journey to the end of the night. (58-59)

Denigrata Herself and Manea's performance does not stop at appearance, it transcends it. In so doing, it permeates black metal's paternal prohibition by forcing it to confront the 'feminine as unnameable other'. Black metal's confrontation with the feminine at Denigrata's shows reveals its narcissism and phobia as an 'obsessional and paranoid structure' (60) that identifies woman-asthreat and ensures its consolidation to protect itself against perceived opposition. As Gayatri Spivak notes, it is only 'when one takes a whack at shaking up the dominant structure, one sees how much more consolidated the opposition is' (1991 16).

Whilst my live gig experience is represented by the Kristevan corpse, my musical and band experience is its antithesis. I have been a writer and metal performer for the last fifteen years but there are a number of reasons why Denigrata is special. The three men in the band identify as feminists and they have been happy to foreground the matrifocal focus of Denigrata, believing that it offers something new to black metal and they enjoy the disruption it represents. In pragmatic terms, this also means some important interior machinery of the band does not function through a gendered hierarchy that would otherwise foreground their opinions regarding Denigrata, over mine or Manea's. This is very important because we all believe that a band should function democratically, that everyone's voice is equal and respected. I have worked with sexist men before and it is impossible to be creative if you are undermined and objectified. Denigrata does not function this way and this is the first time I have worked with feminists.

This is also the first time I have been in a band with another woman, as everything prior to Denigrata was always a masculine space where my presence was mediated and diluted by the patriarchal frame inside which I performed. In Denigrata, the matrifocal structure engages, supports and focuses woman as subject. This has been a developmental issue that has evolved over time and with it has come a fierce and loving friendship with Manea that I describe in terms of sisterhood. It extends beyond the boundaries of a normative woman to woman friendship because we write and play music together; we are involved in creating and working towards our conjoined perichoresis (Hunt-Hendrix 2015) for Denigrata. This is my jouissance, the creativity I take joy in (on en jouit). Jouissance can be a complicated idea that is not only about representing passion. Kristeva states that 'it jettisons the object into an abominable real, inaccessible except through jouissance [...] one does not know it, one does not desire it, one joys in it (on en jouit). Violently and painfully. A passion' (9). It is through this abominable jouissance that Denigrata's matrifocal position has come 
to mean 'she who can wreck the infinite', the 'she' representing a parallax view on the supposed category of woman as represented by the witch-femme of Manea and the witch-hybrid of Denigrata Herself.

My jouissance in Denigrata is nomadic, at once existing as the fiery scream as 'I spit myself out' (3), and occupation of the corpse that 'shows me what I permanently thrust aside in order to live' (3). There is no reconciliation between the polemics, they co-exist violently and painfully, so that my ability to be part of Denigrata's performative text is realised. I am condemned at our live shows for being too much; too much a man on stage, too much a woman for disrupting black metal's juridical orthodoxy. I am, as Denigrata Herself, excess and subtraction. My yearning for that performance is the drive that enshrines and perpetuates it, just as black metal's hegemonic structure enshrine and perpetuate its masculinity. When I began this performance, I could not have known my performative gender excess because it had 'yet to appear to me as a thing [...] laws, connections, and even structures of meaning govern and condition me' (10). I was unable to identify those structures of meaning in black metal because my yearning for Denigrata's perichoresis blinded me. Now, however, it has revealed itself as paternal prohibition, telling me that I am rejected; I am the abject jettisoned for my corporeal performative excess. Kristeva states:

When I seek (myself), lose myself, or experience jouissance - then "I" is heterogeneous. Discomfort, unease, dizziness stemming from an ambiguity that, through the violence of a revolt against, demarcates a space out of which signs and objects arise [...] I experience abjection only if an Other has settled in place and stead of what will be "me". Not at all an Other with whom I identify and incorporate, but an Other who precedes and possesses me, and through such possession causes me to be. A possession previous to my advent: a beingthere of the symbolic that a father might or might not embody. (10)

In black metal, the father is a perpetuating constant that throws his abjectal shadow onto me, possessing me whenever I seek myself through his music. My revolt against him, in my performance in Denigrata, reveals the painful violence conferred upon me for my disruption. Jouissance, as the 'frontier, the repulsive gift of the Other, having become alter ego, drops so that "I" does not disappear in it but finds, in that sublime alienation, a forfeited existence' (9)

My passion for Denigrata's music persists and in so doing, I find myself in black metal's domain of exclusion, an abject within a subject that does not want me there. My sublime alienation that forces my forfeited existence in black metal is my jouissance. Denigrata Herself is my alter ego, my Othered self that I constructed and sacrificed to black metal, 'sacrificing the law to maintain it' (Masciandaro 83) only to have it projected back to me through black metal's paternal prohibition that tries to block and mediate my performative liberation. My jouissance is a bitter, impassioned rage against the black metal 'progressive despot [who] lives at the behest of death, [who] establishes narcissistic power while pretending to reveal the abyss' (Kristeva 16). Black metal is the pretender who's access to the abyss is mediated by the 'special generic authority of black metal, its grottophilic space of absolute refusal' (Masciandaro 83) and that refusal is demarcated through the abjection of the female black metal performer.

This refusal however, has a resistance. My relationship with the band and its matrifocal position is the counter to my subjective experience of black metal's desire to force my sublime 
alienation. My fierce sisterhood with Manea is the epitome of this, existing 'outside of the sacred, [where] the abject is written' (17). The third wave of black metal attempts to cast women as divine but we are witches, never goddesses, we seek a 'demystification of power' (210) in order to represent ourselves as powerful women whose representation signifies revolt. Black metal's attempt to prohibit and mediate women, trying to control our image, representation and performance is met by sorority and solidarity. Black metal can attempt to prohibit and negate Denigrata's performance but we are still there. We are still producing music and performing live, even though the refusal of that performance is ever-present. This will not stop us. We are not 'the chora, [the] receptacle of narcissism' (13); we reject this construction of us as women in black metal and we will not accept its narcissism. The black metal elite's attitude towards us shows its narcissism and paternal prohibitive actions. We stand in counter to this because it will not stop Denigrata from composing and producing black metal.

This disharmony I acknowledge as a vigorous part of my jouissance, that Denigrata Herself and Manea, are recognised as black metal mimesis, as secondary imitators of the masculinity of black metal. But 'even before being like, "I" am not but do separate, reject, ab-ject. Abjection, with a meaning broadened to take in subjective diachrony, is a precondition of narcissism. It is coexistent with it and causes it to be permanently brittle' (13). We reject being like black metal because through our performance, we are black metal. We inhabit, occupy and perform it and in our covetousness of black metal, through our jouissance, the uncertain nomadic status of the deject becomes a totalisable abject-as-subject that claims a rightful place in black metal as an 'abominable real' (9). The abject is subsumed into our subjectivity through our performance and thrown back in the face of black metal's paternal prohibition. Denigrata Herself and Manea's performance is a dramatalurgical strategy that forces disruption into black metal through abject-as-subject, whose 'performing bodies disrupt the status quo, uncover[ing] the understory of hegemonic systems' (Spry qtd in Denzin 2014). And through this uncovering, the 'despot' has revealed himself. We do not 'decay in abeyance' (Kristeva 141), we bloom in our mutiny, occupying the 'land of oblivion' (8) 'between nothing and all' (141).

In my jouissance as Denigrata Herself, I suffer through my passion for black metal and witness the horror of my treatment at its hands, its theme 'the ultimate evidence of such states of abjection within a narrative representation' (141). I extend Kristeva's use of 'narrative' here to include performance, 'abjection within a performance representation'. Denigrata's live show performs back to the empire of black metal's masculinity, by evolving 'textual strategies which "consume" their own biases as they expose and erode those of the dominant discourse' (Tiffin 96), its fragile borders uncoupled from its juridical orthodoxy by women performing black metal. It is fragile because it can be so easily disturbed simply by women, performing. As Kristeva states, 'we have lost faith in One Master Signifier. We prefer to foresee or seduce; to plan ahead, promise a recovery, or esthetise; to provide social security to make art' (209), and make art we will.

Denigrata's perichoresis, its art, photography, live performance and its music, is beauty. It is 'a hypersign around and with the depressive void' (99); black metal's abyss or haptic void (HuntHendrix 55) serves as a totalising force through which Denigrata are constructed. That construction is abjection, the corpse and sublime alienation where we learn that 'totality is indistinguishable from nothingness' (57), that my abject subjectivity represents an excess, a 'dead, static place [whose] 
status is atrophy' (57) because in its nimiety, it is shut down. And even though my live performance as Denigrata Herself feels like it is indistinguishable from nothing because of its totalising force, the melancholic beauty of Denigrata's perichoresis (Hunt-Hendrix 2015) withstands its ignominy. Denigrata Herself and Manea's performance, in the face of their imposed sublimating discourse, stands firm. Any sadness or depression I experience because of the live show is mediated by the art object we are able to produce. Kristeva states:

Sublimation alone withstands death. The beautiful object that can bewitch us into its world seems to us more worthy of adoption than any loved or hated cause for wound or sorrow. Depression recognises this and agrees to live within and for that object [...] the way of speech given to suffering, including screams, music, silence and laughter [...] This is a survival of idealisation - the imaginary constitutes a miracle, but it is at the same time its shattering: a self-illusion, nothing but dreams and words, words, words...It affirms the almightiness of temporary subjectivity - the one that knows enough to speak until death comes. (101-102)

Denigrata's album, our stage performance and our video, are our 'beautiful object' that has bewitched us. All parts of our perichoresis (Hunt-Hendrix 2015) contain my screams in the music and moments of silence where our unity as a band and our laughter reverberate through the charred halls of black metal. We are the survival of our own blackened idealisation that 'manifest[s] lust for the intensity of transitions, of ceding or forcing a system to cede to a radical alterity that reconfigures identity by destroying and overtaking' (Sciscione 176). And that radical alterity for black metal, is Denigrata...

...until death comes...

\section{Bibliography}

De Beauvoir, S. (1997), The Second Sex, London: Vintage Press.

Creed, B. (1997), The Monstrous Feminine: Film, Feminism, Psychoanalysis, London: Routledge.

Daniel, D. (2014), 'Corpsepaint as Necro-Minstrelsy, or Towards the Re-Occultation of Black Blood', Melancology, Alresford, Hants: Zero Books.

Denzin, N. K. (2014), Interpretive Performance Autoethnography, Thousand Oaks, CA: Sage Press.

Elbaz-Luwisch, F, (2005), 'How is Education Possible when there's a Body in the Middle of the Room', Narrative and Experience in Multicultural Education, Thousand Oaks, CA: Sage.

Hunt-Hendrix, H. (2010), 'Transcendental Black metal: a Vision of Apocalyptic Humanism', Hideous Gnosis, Creative Commons.

Hunt-Hendrix, H. (2015), 'The Perichoresis of Music, Art and Philosophy', Mors Mystica, Creative Commons: Schism Press.

Irigaray, L. (1985), The Sex Which Is Not One, New York: Cornell University Press. 
Kristeva, J. (1982), The Powers of Horror: an Essay on Abjection, New York: Columbia University Press.

Lesourd, E. (2013), 'Baptism of Death: Black Metal in Contemporary Art, Birth of a New Aesthetic Category', Helvete: a Journal of Black Metal Theory; vol 1, Punctum Books.

Masciandaro, N. (2010), 'Anti-Cosmosis: Black Mahapralaya', Hideous Gnosis, Creative Commons.

Sciscione, A. (2010), 'Goatsteps Behind My Steps...:Black Metal and Ritual Renewal', Hideous Gnosis, Creative Commons.

Tiffin, H. (1992), The Post Colonial Studies Reader, London: Routledge.

Spivak, G. (1992), 'Can the Subaltern Speak?', The Post- Colonial Studies Reader, London: Routledge. Winterson, J. (29.03.13), '100 Years after the suffragettes', The Guardian, London: Guardian News and Media.

Wittig, M. (1991), The Straight Mind and Other Essays, Boston, MA: Beacon Press. 